\title{
Survival and metamorphosis rate of swimming crab Portunus pelagicus larvae with the use of phytoecdysteroid in the artificial feed
}

\section{Kelangsungan hidup dan kecepatan metamorfosis larva rajungan Portunus pelagicus dengan penggunaan fitoekdisteroid dalam pakan buatan}

\author{
Andi Nikhlani*, Komsanah Sukarti \\ Department of Aquaculture, Faculty of Fisheries and Marine Science, Mulawarman University, Samarinda \\ Jl. Gunung Tabur, Campus Gunung Kelua, Samarinda. Telp. 0541-749482 \\ *E-mail: andini.makmur@yahoo.com
}

\begin{abstract}
The survival rate of blue swimming crabs and the larval metamorphosis processes are still low in hatcheries. The objective of this study was to evaluate the effects of different phytoecdysteroids doses on both the survival and the rate of Blue swimmer crab larvae metamorphosis. The study consisted of four different phytoecdysteroids treatments, namely: control $(0 \mathrm{mg} / 100 \mathrm{~g}$ of feed), $1 \mathrm{mg} / 100 \mathrm{~g}$ of feed, $2 \mathrm{mg} / 100 \mathrm{~g}$ of feed, and $4 \mathrm{mg} / 100 \mathrm{~g}$ of feed. Each treatment was replicated three times. The survival rate of the larvae was analyzed through analysis of variance, while the rate of larval metamorphosis was descriptively analyzed. The results showed that the dose of phytoecdysteroid of $2 \mathrm{mg} / 100 \mathrm{~g}$ of artificial feed resulted in the highest survival and the fastest metamorphosis speed of crab larvae for zoea- 2 and zoea- 3 , and the dose of $4 \mathrm{mg} / 100 \mathrm{~g}$ of artificial feed for stadia megalopa and crablet.
\end{abstract}

Keywords: phytoecdysteroids, survival rate, metamorphosis, blue swimming crab

\begin{abstract}
ABSTRAK
Kelangsungan hidup rajungan dalam pembenihan masih rendah, dan proses metamorfosis larva masih lambat. Tujuan penelitian ini adalah untuk mengevaluasi pengaruh pemberian fitoekdisteroid dosis berbeda terhadap kelangsungan hidup dan kecepatan metamorfosis larva rajungan. Penelitian ini terdiri atas empat perlakuan dosis fitoekdisteroid yang berbeda, yaitu: kontrol ( $0 \mathrm{mg} / 100 \mathrm{~g}$ pakan), $1 \mathrm{mg} / 100 \mathrm{~g}$ pakan, $2 \mathrm{mg} / 100 \mathrm{~g}$ pakan, dan $4 \mathrm{mg} / 100 \mathrm{~g}$ pakan dengan masing-masing perlakuan dilakukan tiga kali ulangan. Kelangsungan hidup larva dianalisis menggunakan analisis sidik ragam, sedangkan kecepatan metamorfosis larva dianalisis secara deskriptif. Hasil penelitian menunjukkan bahwa dosis fitoekdisteroid sebanyak $2 \mathrm{mg} / 100 \mathrm{~g}$ pakan buatan menghasilkan kelangsungan hidup tertinggi dan proses metamorfosis larva rajungan tercepat untuk stadia zoea-2 dan zoea-3, serta dosis $4 \mathrm{mg} / 100 \mathrm{~g}$ pakan buatan untuk stadia megalopa dan crablet.
\end{abstract}

Kata kunci: fitoekdisteroid, kelangsungan hidup, metamorfosis, rajungan

\section{INTRODUCTION}

Portunus pelagicus, or the blue swimming crab, is one of the most valuable commercial crabs in the world and especially in Indonesia and constitutes part of the fishery products with high market demand. The export volume of crabs has increased from 23 to 25 million tonnes/year, which was in accordance with the crab catches that has also increased over the years. Fujaya (2011) mentioned that Indonesia contributed for $20 \%$ of the world crab production in 2008 and ranked as the second largest crab producing country after China. However, crab availability in Indonesia yearly decreases by $20-30 \%$ as a consequence of both increasing human needs and environmental pressures. Thus, it is important that crab supplies increase to fulfill the increasing demands through cultivation as a technique of crab production.

The blue swimmer crab can be cultivated in the pond. Larvae, however, can only be obtained through capture in natural habitat. The breeding 
of crabs has been done, but no satisfying results have reached so far due to fluctuation in the survival of the larvae, ranging from 0.004 to $0.25 \%$ (Ikhwanuddin et al., 2013). The low survival rate of crab larvae generally occurs when the larvae are in the early developmental stages such as zoea-4 and megalopa (Fujaya et al., 2008) and is mostly due to molting failure (Fujaya et al., 2014) which occurs due to the lack of ecdysteroids supply in the body of the crab (larvae).

In addition to the problem of low larvae survival rate, the metamorphosis rate of crab (larva) is also important to note. Accelerating the metamorphosis processes of crab larvae in a qualitative way is of capital importance in saving production costs. The rate of larval metamorphosis depends on the ability of the larva to molting. The more the larva performs molting, the faster the larvae will grow (Fujaya et al., 2014).

The use of exogenous hormones to increase the volume of the hormones in the body has been done in both higher animals and humans (Fujaya \& Trijuno, 2007; Bakrim et al., 2008; Fujaya et al., 2008; Techa \& Chung, 2015) excepts in crabs. Azra et al. (2012) used 20-Hydroxyecdysone (20-HE) to stimulate molting in crabs, while the spinach phytoecdysteroids (Amaranthaceae) was used to stimulate molting in the production of mangrove crab Scylla serrata (Aslamyah \& Fujaya, 2010; Fujaya, 2011; Fujaya et al., 2011; Fujaya et al., 2012; Fujaya et al., 2014; Herlinah et al., 2015). In addition, phytoecdysteroids derived from mulberry leaf extract have also been used for the development of Portunus pelagicus larvae (Fujaya et al., 2014; Ahmad et al., 2015). Fujaya et al. (2014) and Ahmad et al. (2015) used mulberry leaf extract Morus alba at doses ranging from $1-4 \mathrm{mg} / 100 \mathrm{~g}$ of feed to $4-400 \mathrm{mg} / 100 \mathrm{~g}$ of feed.

This study aims to evaluate the effects of different phytoecdysteroids doses on both the survival rate and the rate of blue swimmer crab larvae metamorphosis. The responses of Portunus pelagicus larvae to variation in phytoecdysteroids doses in artificial feed can be used as a reference in formulating artificial feed containing phytoecdysteroids for the maintenance of crab larvae.

\section{MATERIALS AND METHODS}

This research was conducted at the Juvenile Center for Brackish and Marine Water (BBSAPAL) in Manggar, Balikpapan. The study used a completely randomized design consisting of four different phytoecdoidoid doses as follows: control $(0 \mathrm{mg} / 100 \mathrm{~g}$ of feed), $1 \mathrm{mg} / 100 \mathrm{~g}$ of feed, $2 \mathrm{mg} / 100 \mathrm{~g}$ of feed, and $4 \mathrm{mg} / 100 \mathrm{~g}$ of feed. Each treatment was replicated three times.

The larvae used in the present study were obtained from crab broodstock weighing $173 \pm 8.5$ $\mathrm{g}$ with a carapace width and length of $12.50 \pm 3.5$ $\mathrm{cm}$ and $6.7 \pm 2.7 \mathrm{~cm}$, respectively. The larvae were selected based on their health or quality and then divided into groups. Healthy larvae were characterized by their swimming at the water column and moving toward the surface of the water (post-hatch and zoea-1 stages), due to the positive phototaxis characteristics of approaching lights. Meanwhile, unhealthy larvae were characterized by their settling at the bottom of the basins.

The container used in this research were 12 $\left(2 \times 1 \times 0.5 \mathrm{~m}^{3}\right)$ concrete basins equipped with an aeration system and filled with $500 \mathrm{~L}$ of sea water for maintaining the crabs. Seawater was used in the larval maintenance stage and brought from the coastal water of Manggar, Balikpapan. The used seawater had a salinity of 29-33 g/L, a temperature of $26-33{ }^{\circ} \mathrm{C}$, and a dissolved oxygen of $5-6 \mathrm{mg} / \mathrm{L}$. Prior to use, maintenance media was sterilized using chlorine $150 \mathrm{mg} / \mathrm{L}$, then neutralized with sodium thiosulfate $\left(\mathrm{Na}_{2} \mathrm{~S}_{2} \mathrm{O}_{3}\right) 25$ $\mathrm{mg} / \mathrm{L}$ and aerated for 24 hours.

The phytoecdysteroids, used in the present research, was derived from spinach leaf extract Amaranthaceae tricolor. The extract was obtained from the Laboratory of Fisheries and Marine Biotechnology, Center for Research Activities (PKP), Hasanuddin University. The preparation of phytoecdysteroids-contained feed commenced by weighing the artificial feeds and using $100 \mathrm{~g}$ for each treatment. Furthermore, the feed was spread on a traditional dryer (tampah) in order to be enriched with the phytoecdysteroids hormone, which was diluted with $10 \mathrm{~mL}$ of absolute ethanol in a sampling bottle with the appropriate dose for each treatment and then shaken until it became totally dissolved and homogenized. The hormones with appropriate doses for each treatment were inserted into the sprayer and sprayed on the artificial feed until evenly distributed. The feed was air-dried at room temperature $\left(26-27{ }^{\circ} \mathrm{C}\right)$ for 24 hours. The dried feed was then packed in a plastic bag, tightly closed and kept in a dry place until further usage.

The given natural feed consisted of Brachionus sp. and nauplii Artemia sp. The used artificial of feed comprised of three types, Japonicus-0 (J0) 
for the zoea-1 and zoea-2 larvae, Japonicus-1 (J1) for the zoea-3 larvae, Japonicus-2 (J2) for zoea-4 larvae and Japonicus-3 (flake form) for megalopa stage larvae. Powder form feed, which was given to the zoea-megalopa stage larvae had a protein content of $48 \%$ and a fat content of $8 \%$, while the flake-type feed had a protein content of $48-53 \%$ and fat content of 3-5\%.

The selected larvae were dispersed into preprepared basins with a total of 350,000 each. Larvae maintenance was performed for one month (indoor) from the zoea-1 stage to the crablet-1 stage. Water change and aeration were carried out daily. Natural feeding and artificial feeding were done daily at feeding frequency of 2 i.e. at 7:00 am and 5:00 pm, ad libitum. The feeding schedule is presented in Table 1 .

\section{Parameters of the research}

\section{Larvae survival rate}

The survival rate of crab larvae, at each stage, was calculated based on the number of larvae that successfully morphed into the next stage. The larvae that successfully metamorphosed were considered as the number of initial larvae used to calculate the survival rate of the next larval stage. The survival rate of larvae was observed at the beginning and end of the developmental stages and was calculated using the formula developed by Effendie (1997):

$$
\mathrm{SR}=\mathrm{Nt} / \mathrm{No} \times 100
$$

Note:

$\mathrm{SR}=\operatorname{survival}(\%)$

$\mathrm{Nt}=$ the number of the alive fish at the final observation (individuals)

No $=$ the number of the alive fish at the initial observation (individuals)

\section{Metamorphism rate of crab larvae}

The rate of crab larvae metamorphosis was observed daily at the specific hours (8:00 to 9:00 am) through the sampling of $250 \mathrm{~mL}$ of water in each basin (three samples per basin). The observed larvae were not replaced in the experimental basins. Samples of larvae were taken, collected and inserted into small plastic bottles containing alcohol, then identified under a microscope. The characteristics of morphological stages were determined based on the larval stage index (LSI) that follows the formula developed by Fujaya et al. (2014) (Table 2).

$$
\mathrm{LSI}=\{(\mathrm{St} \times \mathrm{Lt})+(\mathrm{Si} \times \mathrm{Li})\} / \mathrm{Ts}
$$

Description: LSI: larval stage index, St: following larval stage, Si: previous larval stage, $\mathrm{Lt}$ : number of samples for the next stage, $\mathrm{Li}$ : number of samples for the previous stage, Ti: total number of samples.

\section{Data analysis}

The data on larvae survival rate, before being analyzed through variance test (ANOVA), were tested for homogeneity with Bartlett test. If the

Table 1. Natural and artificial feeding schedules

\begin{tabular}{|l|l|l|l|l|l|l|l|l|l|l|l|l|l|l|l|l|l|l|l|l|l|}
\hline Days & 1 & 2 & 3 & 4 & 5 & 6 & 7 & 8 & 9 & 10 & 11 & 12 & 13 & 14 & 15 & 16 & 17 & 18 & 19 & 20 & 21 \\
\hline NF & & & & & & & & & & & & & & & & & & & & & \\
\hline AF & & & & & & & & & & & & & & & & & & & & \\
\hline
\end{tabular}

Note: $\mathrm{NF}=$ natural feed (Brachionus sp. and Artemia sp.), AF = artificial feed (J0, J1, J2, and flake).

Table 2. Larval stage index (LSI)

\begin{tabular}{ccc}
\hline Larval stages & Estimated LSI & LSI inference \\
\hline Zoea 1 (Z1) & $1-1.5$ & 1 \\
Zoea 2 (Z2) & $1.6-2.5$ & 2 \\
Zoea 3 (Z3) & $2.6-3.5$ & 3 \\
Zoea 4 (Z4) & $3.6-4.5$ & 4 \\
Megalopa (M) & $4.6-5.5$ & 5 \\
Crablet (C) & $5.6-6.5$ & 6 \\
\hline
\end{tabular}


Bartlett test shows that the data is homogeneous, then the data can be analyzed by ANOVA test, while the non-homogeneous data will be transformed into squared root data. If significant differences were observed between treatments, the data was further tested via BNT test (Hanafiah, 2011). The rate of larval metamorphosis was descriptively analyzed.

\section{RESULTS AND DISCUSSION}

\section{Larvae survival rate}

The highest crab larvae survival rate was observed in the zoea stage $(54.33 \pm 1.05 \%)(\mathrm{P}<0.05)$ i.e. in the phytoecdysteroid supplementation 2 $\mathrm{mg} / 100 \mathrm{~g}$ of feed treatment (Table 3). Thus, a dose of $2 \mathrm{mg} / 100 \mathrm{~g}$ of feed can support optimal molting in larvae. They showed limitations in exploiting the hormones contained in the artificial feed to stimulate molting. According to Azra et al. (2012), the main role of the ecdysteroids supplementation in crabs is to control the turn of crustacean molting. Fujaya et al. (2008) and Pamuru et al. (2012), who stated that the growth and survival of crustaceans is periodically controlled by neuropeptide and ecdysteroid hormones. Herlinah et al. (2014) also stated that both inadequate and excessive hormone administration will not be effectively used by the crabs. Fujaya et al. (2012) mentioned that errors in the timing of hormone administration and the quantity of hormone will have consequences on the organism. High concentrations of hormones in the blood vessels indicate that cells build barriers in order to maintain the homeostatic state (balanced), leading to low doses of hormones that are insufficient to stimulate actions. Fujaya and Trijuno (2007), Niwa and Niwa (2014), Techa and Chung (2015), and Ahmad et al. (2015) explained that the high hormone concentrations inhibit the production receptors and the ability of cell receptors to bind to hormones causing decrement in order to inhibit protein formation, resulting in growth and molting inhibition.

It can be observed, in Table 3, that the highest crab larvae survival rates were obtained in the megalopa and crablet stages and were $10.1 \pm 0.68 \%$ and $9.5 \pm 0.44 \%$ (phytoecdysteroid supplementation at a dose of $4 \mathrm{mg} / 100 \mathrm{~g}$ of feed), respectively. Those high survival rates are thought to be due to the dose of phytoecdysteroid (4 $\mathrm{mg} / 100 \mathrm{~g}$ of feed) that was administered through artificial feed and could be optimally utilized by larvae in the crablet stage. The high survival rates observed in megalopa and crablet stages, at a dose of $4 \mathrm{mg} / 100 \mathrm{~g}$ of feed, were significantly different to those in the obtained in the zoea stage i.e. at a dose of $2 \mathrm{mg} / 100 \mathrm{~g}$ of feed. Thus, the needs of the crab larvae for the phytoecdysteroids supply in the body are affected by both the age and stages of the larvae, implying that megalopa and crablet need more phytoecdysteroids than the zoea. This was in accordance with Azra et al. (2012), Niwa and Niwa (2014) who suggested that the 20-HE concentration increased with the age of larvae, where the needs for 20-HE differed in the larval growth at each stage. Ahmad et al. (2015) also stated that the larval development the larvae survival of $10.60 \%$ at a concentration of 4 $\mathrm{mg} / 100 \mathrm{~g}$ of feed for all stages decreased at higher concentrations. The results obtained by Ahmad $e t$ $a l$. (2015) were not significantly different to those of the present study.

The survival rates of the crab larvae from the zoea-4 stage to the megalopa stage were lower when compared to those from the zoea- 1 to zoea4. This could be due to the fact that in the zoea-4 stage, periopod-1 has begun to enlarge in order to form a claw and in the megalopa stage, leg and claw already had clear shapes. The development of legs and claws that occurred in both the zoea4 stage and the megalopa stage allowed the occurrence of cannibalism. This phenomenon explained the high frequency of cannibalism that occurred when the zoea- 4 metamorphosed into megalopa. This is supported by Fujaya et al.

Table 3. Survival rates of Portunus pelagicus crab larvae (at each stage) (\%) that were given phytoecdysteroids through feed (at different doses)

\begin{tabular}{cccc}
\hline Treatments & Zoea $(\%)$ & Megalopa $(\%)$ & Crablet $(\%)$ \\
\hline Control & $34.16 \pm 0.49 \mathrm{a}$ & - & - \\
$1 \mathrm{mg} / 100 \mathrm{~g}$ & $33.93 \pm 0.51 \mathrm{a}$ & - & - \\
$2 \mathrm{mg} / 100 \mathrm{~g}$ & $54.33 \pm 1.05 \mathrm{~b}$ & $7.86 \pm 0.60 \mathrm{e}$ & $1.46 \pm 0.17 \mathrm{c}$ \\
$4 \mathrm{mg} / 100 \mathrm{~g}$ & $28.63 \pm 0.81 \mathrm{a}$ & $10.10 \pm 0.68 \mathrm{e}$ & $9.50 \pm 0.44 \mathrm{~d}$ \\
\hline
\end{tabular}

Note: Different letters in the same column showed no significant difference between treatments $(\mathrm{P}<0.05)$. 
(2014) who stated that megalopa actively swims, already has a pair of claws that serve to capture prey very high cannibalism level.

\section{The rate of metamorphosis in crab larvae}

The larvae in the phytoecdysteroids treatment, at a dose of $2 \mathrm{mg} / 100 \mathrm{~g}$ of feed, succeeded in attaining the fastest zoea- 2 and zoea- 3 stages i.e. on the 4th day with the LSI value of 1.6 and the 8th day with the LSI value of 2.7. The larvae in the phytoecdysteroid $4 \mathrm{mg} / 100 \mathrm{~g}$ of feed treatment had the fastest zoea- 4 stage i.e. on day 10 with an LSI on 3.9. The larvae in the $2 \mathrm{mg} / 100 \mathrm{~g}$ of feed treatment also were also fast in reaching the megalopa stage on day 13 with an LSI value of 4.6. Meanwhile, the larvae in the phytoecdysteroids treatment of $4 \mathrm{mg} / 100 \mathrm{~g}$ of feed were the fastest in reaching the crablet stage, from the stage of larvae maintenance up to day 17 with an LSI value of 5.8 (Table 4 ). The total time required from zoea- 1 to zoea-2, in this study, was 4-6 days, which is lower compared to that of the research conducted Ahmad et al. (2015) which was 2-6 days. The time required for the zoea- 2 stage to morphe into zoea-3 in this study was 3-4 days which was slower compared to that mentioned in Ahmad et al. (2015) research, was 1-4 days.

In the present study, the required time for zoea3 larvae to metamorphose into zoea-4 was $1-3$ days that was faster than the time demonstrated by Ahmad et al. (2015) which was 3-4 days. Meanwhile, the time required for zoea-4 larvae to metamorphose into megalopa was 4-6 days and the megalopa stage lasted for approximately 5-7 days (in this study). After the above metamorphoses, the megalopa will turn into crablet. According to Fujaya et al. (2014), after the megalopa stage, the larvae will transform into juveniles which are already at young crab stage. The changes, at each level, begins with molting. The total time required for the development from zoea to crablet was 17-19 days in the present study.
Although slower than in the previous studies, there was at least a stage in this study that had a faster metamorphosis rate compared to previous studies i.e. the stage with the $2 \mathrm{mg} / 100 \mathrm{~g}$ feed treatment. Indeed, the larvae that treatment entered faster in both the zoea-3 and megalopa stages compared to other treatments and the larvae in the $4 \mathrm{mg} / 100 \mathrm{~g}$ dose only needed a day to metamorphose from zoea-3 to zoea-4 when compared to other treatments. This is suspected to be a consequence of feeding the larvae on (the day 6) artificial feed containing phytoecdysteroids at a dose of $2 \mathrm{mg} / 100 \mathrm{~g}$ feed. In a study conducted by Ahmad et al. (2015), the time it took larvae to metamorphose from the zoea- 3 stage to the zoea4 stage was $4-5$ days. The dose of $2 \mathrm{mg} / 100 \mathrm{~g}$ feed is thought to be optimally utilized by larvae during the molting process. Spinach extract contains phytoecdysteroids, including steroid groups, which can rate up both molting and growth when added to the feed. It is also expected to improve the efficiency of feed protein utilization. According to Aslamyah and Fujaya (2010), Fujaya et al. (2011), Pamuru et al. (2012), and Ahmad et al. (2015) steroid hormones can increase protein metabolism in cells. Those hormones will promote the growth of crabs, triggering the molting process and the formation of new shells to accommodate the enlarging crabs. Kuballa and Elizur (2007) suggested that phytoecdysteroids have anabolic effects as the increase protein synthesis. The most prominent metabolic action of steroid hormone is the activation of protein metabolism. Furthermore, it is believed that molting is physiologically controlled by the molting hormones. Thus, molting induction using phytoecdysteroids can maintain excellent metabolic rate and the availability of sufficient energy to accelerate the molting process.

In the $4 \mathrm{mg} / 100 \mathrm{~g}$ of feed treatment, the fastest larval metamorphosis occurred at the zoea-3 stage, when the larvae were nine days

Table 4. Average rates of metamorphosis in Portunus pelagicus crab larvae based on the larval stage index (LSI)

\begin{tabular}{|c|c|c|c|c|c|c|c|c|c|c|c|c|c|c|c|c|}
\hline \multirow{2}{*}{$\mathrm{P}$} & \multicolumn{16}{|c|}{ Age of the larvae (days) } \\
\hline & 4 & 5 & 6 & 7 & 8 & 9 & 10 & 11 & 12 & 13 & 14 & 15 & 16 & 17 & 18 & 19 \\
\hline 0 & 1.2 & 1.4 & 1.9 & 2 & 2.2 & 2.6 & - & - & - & - & - & - & - & - & - & - \\
\hline 1 & 1.3 & 1.7 & 2.1 & 1.9 & 2 & 2.6 & 2.8 & 3.3 & - & - & - & - & - & - & - & - \\
\hline 2 & 1.6 & 1.7 & 2.4 & 2.6 & 2.7 & 2.9 & 3.2 & 3.7 & 3.8 & 4.6 & 4.9 & 4.9 & 5.1 & - & - & - \\
\hline 4 & 1.4 & 1.6 & 1.7 & 2.4 & 2.5 & 2.9 & 3.9 & 4.1 & 4.3 & 4.4 & 4.8 & 5.1 & 5.4 & 5.8 & 5.9 & 6.1 \\
\hline
\end{tabular}

Note: P: treatments (mg/100 g of feed), - : 100\% mortality. 
old. Allegedly, the digestive organs of the crabs, on day 9, have already entered the definitive phase, signifying that they were able to produce digestive enzymes to break down the artificial feed into its full potential. This is supported by Serrano and Traifalgar (2012) who stated that the enzymatic activities of amylase, trypsin, and leucine aminopeptidase in mangrove crab larvae generally started at the zoea 3 stage. In addition, a dose of phytoecdysteroids $(4 \mathrm{mg} / 100 \mathrm{~g}$ of feed) can stimulate the larvae for faster molting process during that stage. The need for different hormonal doses at each larval development stage is thought to be due to the zoea stages, where the larvae still go through developmental stages in order to perfect the body cells which are related to the ability of the cells to respond to a given hormone and to pass it to the target cells. The need for ecdysteroids is lower compared to their need for crab larvae at both the megalopa and crablet stages. This is supported by the statement of Bakrim et al. (2008), Azra et al. (2012), and Ahmad et al. (2015) on the fact that the 20-HE concentration required by the larvae to support the occurrence of molting increases along with the life cycle of the larvae. Herlinah et al. (2015) also stated that ecdysteroid levels at certain doses (40.76-175.20 mg/L) were more effective and sufficient in fulfilling mud crab needs to initiate a molting process supported by an optimal environment.

Bakrim et al. (2008), Fujaya et al. (2014), Niwa and Niwa (2014), and Ahmad et al. (2015) suggested that the ecdysteroid is a major steroid hormone in arthropods that regulate physiological functions, such as growth, metamorphosis, and reproduction. This hormone is secreted by the $\mathrm{Y}$ organ in the form of ecdysone. In the hemolymph, this hormone is converted into 20-HE active hormone by the 20-hydroxylase enzyme found in the epidermis of other organs and tissues. Zoea stage larvae require $2 \mathrm{mg} / 100$ $\mathrm{g}$ of feed of phytoecdysteroids, while megalopa and crablet stages require $4 \mathrm{mg} / 100 \mathrm{~g}$ of feed of phytoecdysteroids for growth.

\section{CONCLUSION}

Based on the results of this research, both the survival rate and the metamorphosis rate of the larvae could be improved by supplementing phytoecdysteroid, at a dose of $2 \mathrm{mg} / 100 \mathrm{~g}$ of feed, the metamorphic stages of zoea. Phytoecdysteroid formulation in artificial feed, at a dose of $4 \mathrm{mg} / 100$ $\mathrm{g}$ of feed, can increase both the survival and metamorphosis rate of larvae during megalopa and crablet stages.

\section{REFERENCES}

Ahmad F, Fujaya Y, Trijuno DD, Aslamyah S. 2015. Acceleration of blue swimming crab Portunus pelagicus larvae development by phytoecdysteroid. Journal Aquaculture Indonesiana 16: 50-55.

Aslamyah S, Fujaya Y. 2010. Stimulation of molting and growth of mangrove crab Scylla spp. through artificial food made of food waste enriched with spinach extract.Indonesian Journal of Marine Science 15: 170-178.

Azra MN, Safiah J, Abol Munafi AB, Ikhwanuddin M. 2012. Effect of 20 hydroxyecdysone on early larval stages of blue swimming crab's Portunus pelagicus (Linnaeus 1758). UMT 11th International Annual Symposium on Suistainability Science and Management 09th11th July 2012, Trengganu, Malaysia.

Bakrim A, Maria A, Sayah A, Lafont R, Takvoriant N. 2008. Ecdysteroid in spinach Spinacia oleracea L : Biosynthesis, transport and regulation of levels. Plant Physiology and Biochemistry 46: 844-854.

Effendie MI.1997. Biologi Perikanan. Yayasan Pustaka Nusantara. Yogyakarta.

Fujaya Y, Trijuno DD. 2007. Profil hormon ekdisteroid dalam haemolimph kepiting bakau Scylla olivacea selama periode molting dan pematangan gonad [Laporan Penelitian Fundamental]. Makassar: Universitas Hasanuddin.

Fujaya Y, Suryati E, Nurcahyono E, Nur A. 2008. Titer ekdisteroid hemolimp dan ciri morfologi rajungan Portunus pelagicus selama fase molting dan reproduksi. Torani 18: 266-274.

Fujaya Y. 2011. Growth and moulting of mud crab administered by different doses of vitomolt. Jurnal akuakultur Indonesia 10: 24-28.

Fujaya Y, Aslamyah S, Usman Z. 2011. Molting response, growth, and mortality of mangrove crab Scylla olivacea supplemented with vitomolt via injection and artificial food. Indonesian Jurnal of Marine Science 16: 211218.

Fujaya Y, Aslamyah, Fujaya L, Alam N. 2012. Budidaya dan bisnis kepiting lunak: stimulasi molting dengan ekstrak bayam. Surabaya: Briliant International.

Fujaya Y, Trijuno DD, Nikhlani A, Cahyono I, 
Hasnidar. 2014. The use of mulberry Morus alba extract in the mass production of blue swimming crab Portunus pelagicus L. larvae to overcome the mortality rate due to molting syndrome. Aquatic Science and Technology 2: $1-14$.

Hanafiah KA. 2011. Rancangan Percobaan: Teori dan Aplikasi. Jakarta: Rajawali Press.

Herlinah, Tenriulo A, Suryati E. 2014. Hormone ecdysterone of mulberry leaves extract, Morus spp. as moulting stimulant on mangrove crabs. Jurnal Riset Akuakultur 9: 387-397.

Herlinah, Tenriulo A, Septiningsih E, Suwoyo HS. 2015. Survival and response molting of mud crab Scylla olivacea injected with murbey Morus spp. leave extract. Jurnal Ilmu dan Teknologi Kelautan Tropis 7: 247-258.

Ikhwanuddin M, Azra MN, Sung YY, Ambok Bolong AB, Long SM. 2013. Growth and survival of blue swimming crab Portunus pelagicus reared on frozen and artificial foods. Agricultural Sciences 4: 76-82.

Kuballa A, Elizur A. 2007. Novel molecular approach to study moulting in crustaceans. Bulletin of Fisheries Research Agency. 20: 53-57.

Niwa R, Niwa YS. 2014. Enzymes for ecdysteroid biosynthesis: Their biological functions in insects and beyond.Bioscience, Biotechnology and Biochemistry 78: 1283-1292.

Pamuru RR, Rosen O, Manor R, Chung JS, Zmora N, Glazer R, Aflalo ED, Weil S, Tamone SL, Sagi A. 2012. Stimulation of molt by RNA interference of the molt-inhibiting hormone in the crayfish Cherax quadricarinatus. General and Comparative Endocrinology 178: 227236.

Serrano AE, Traifalgar RF. 2012. Ontogeny and or induction of digestive enzymes in Scylla serrata larvae fed live or arificial feeds or their combination. AACL Bioflux 5: 101-111.

Techa S, Chung JS. 2015. Ecdysteroids regulate the levels of molt-inhibiting hormone(MIH) expression in the blue crab Callinects sapidus. PloS ONE 10: e0117278. 